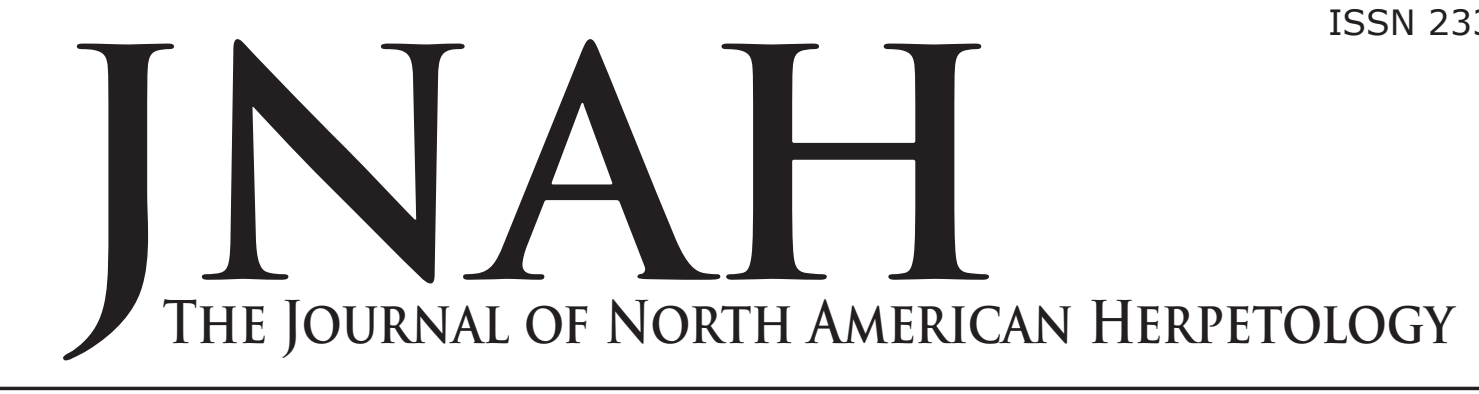

\author{
Volume 2014(1): 7-20 \\ 31 January 2014 \\ jnah.cnah.org
}

\title{
SNAKE ASSEMBLAGE STRUCTURES AND SEASONAL ACTIVITY PATTERNS ON A MILITARY BASE IN SOUTH-CENTRAL PENNSYLVANIA: LAND MANAGEMENT IMPLICATIONS FOR SNAKE CONSERVATION
}

\author{
WALTER E. MESHAKA, JR. ${ }^{1}$ AND PABLO R. DELIS ${ }^{2}$ \\ ${ }^{1}$ Section of Zoology and Botany, State Museum of Pennsylvania, 300 North Street, Harrisburg, PA \\ 17120, U.S.A. wmmeshaka@pa.gov [author for correspondence] \\ ${ }^{2}$ Department of Biology, Shippensburg University, 1871 Old Main Drive Shippensburg, PA 17257, U.S.A.
}

\begin{abstract}
We ascertained the assemblage structures of snakes occurring in a mixed habitat matrix of natural and disturbed habitats during 2008-2011 at Letterkenny Army Depot (LEAD), a 7200 ha U.S. Army base in south-central Pennsylvania, to understand the patterns of species abundance as they related to habitat type of managed lands. We detected eight species in 12 sites comprising natural and disturbed habitats of wetlands, forest, and thicket and open fields. The Common Gartersnake (Thamnophis sirtalis) occurred in the most sites, the Red-bellied Snake (Storeria occipitomaculata) was the rarest species in the study. Two to six species occupied each site and were distributed unevenly. Dynamics of assemblages could be explained in part by habitat and also by the presence of the North American Racer (Coluber constrictor). All species for which data were available exhibited a unimodal pattern to their seasonal activity (mostly May and June); however, seasonal activity peaks differed between sexes. Sex ratios varied among species but were consistently female-biased in the Common Gartersnake and Ring-necked Snake (Diadophis punctatus) in Pennsylvania and surrounding areas. As elsewhere in Pennsylvania and the Northeast, body sizes of adults were larger for species syntopic with the North American Racer than for species not syntopic with this potential predator. We found a degree of predictability with respect to snake assemblage dynamics among habitats at LEAD, which in turn can prove useful in resource management of this large and protected human-impacted system.
\end{abstract}

Key words: conservation, ecology, Pennsylvania, snakes

\section{INTRODUCTION}

Snake assemblage dynamics is not a common research topic in Pennsylvania or in the northeastern United States. Pennsylvania, for instance, has 22 indigenous species of snakes (Meshaka and Collins, 2009) with several, including state-listed species such as the Copperhead (Agkistrodon contortrix), occupying the most northern edges of their geographic range (Conant and Collins, 1998). The dynamic interactions of these species along challenging biogeographical boundaries might impact the persistence, increase, or decline of their populations in the region.

Studies in Pennsylvania and surrounding areas have demonstrated the importance of primary and secondary grasslands to snakes and quantified their respons- es to patch size and presence of the predatory North American Racer (Coluber constrictor) (Kjoss and Litvaitis, 2001; Meshaka et al., 2009). The North American Racer occurs in large patches of grasslands or thickets, and syntopic species tend to be relatively large in body size (Kjoss and Litvaitis, 2001; Meshaka et al., 2009). In areas of syntopy, the Common Gartersnake was either abundant if the North American Racer was uncommon (Kjoss and Litvaitis, 2001) or absent if the North American Racer was dominant (Meshaka et al., 2009). In small patches, the Common Gartersnake could be abundant (Kjoss and Litvaitis, 2001; Meshaka et al., 2009). In all aforementioned cases, assemblages were uneven.

We undertook a long-term snake monitoring project that 
encompassed 12 sites comprised of grassland, wetland, open and closed canopy forest, and disturbed habitats on approximately 1800 ha (Zone 2 - Buffer Zone) of a 7200 ha military site in south-central Pennsylvania. Our goals were to examine the composition of snake assemblages among habitats, test earlier findings concerning grassland assemblage dynamics, and provide temporal activity patterns. This information together with assemblage structure data, could be used to expand our knowledge of the natural history of snake species in Pennsylvania and to formulate local and regional resource management protocols.

\section{MATERIALS AND METHODS}

As per Delis et al. (2010), Letterkenny Army Depot

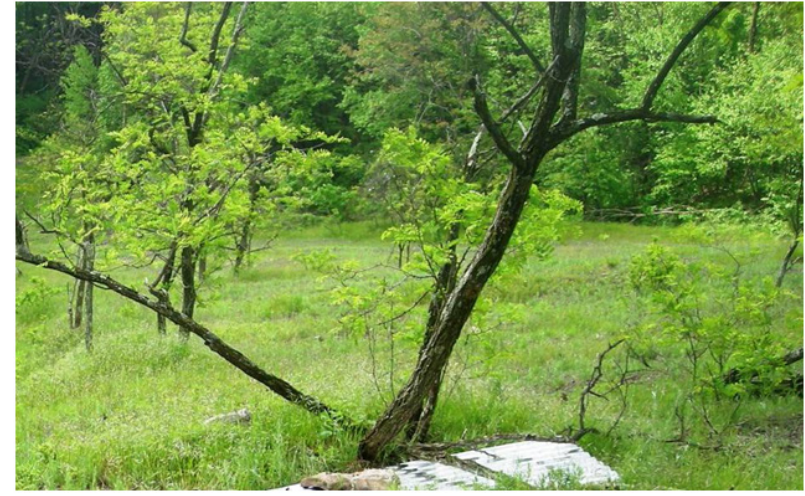

Figure 1. Bombing Range 1. Letterkenny Army Depot, Chambersburg, Franklin County, Pennsylvania. Photographed by P.R. Delis.

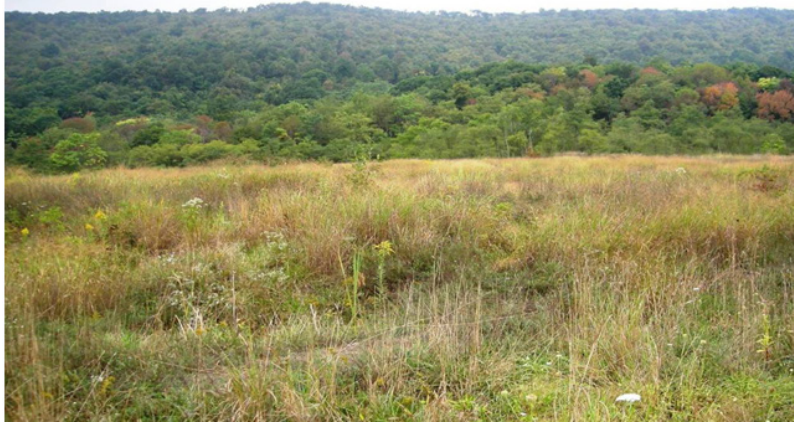

Figure 2. Bombing Range 2. Letterkenny Army Depot, Chambersburg, Franklin County, Pennsylvania. Photographed by P.R. Delis.

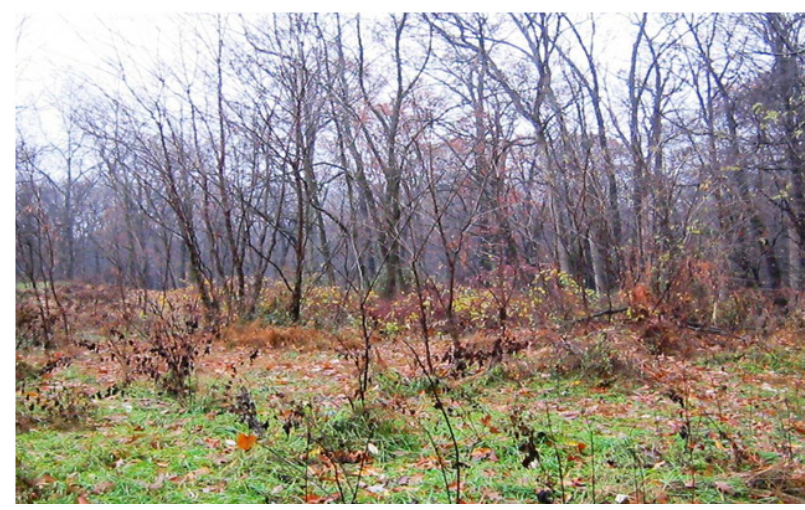

Figure 3. Log Cabin-Field. Letterkenny Army Depot, Chambersburg, Franklin County, Pennsylvania. Photographed by P.R. Delis.
(LEAD) is a 7200 ha federally-owned parcel with valleys and mild hills ranging 199-396 $\mathrm{m}$ in elevation located in Franklin County in south-central Pennsylvania $\left(39^{\circ} 58^{\prime} \mathrm{N}\right.$ Lat., $77^{\circ} 42^{\prime} \mathrm{W}$ Long). The vegetation is dominated by mixed deciduous forest and by disturbed grasslands at various stages of succession that are impacted by agricultural and other human activities. Aquatic systems were comprised of streams, vernal and autumnal pools, permanent woodland pools, gravel pits, and agricultural ponds. We conducted this study in the Buffer Zone of LEAD otherwise known as Zone 2, a 1800 ha parcel located in the northwest sector of the installation at the base of North Mountain along the Kittatinny Ridge of the Blue Mountain range.

We chose 12 sites on approximately 1000 ha of the

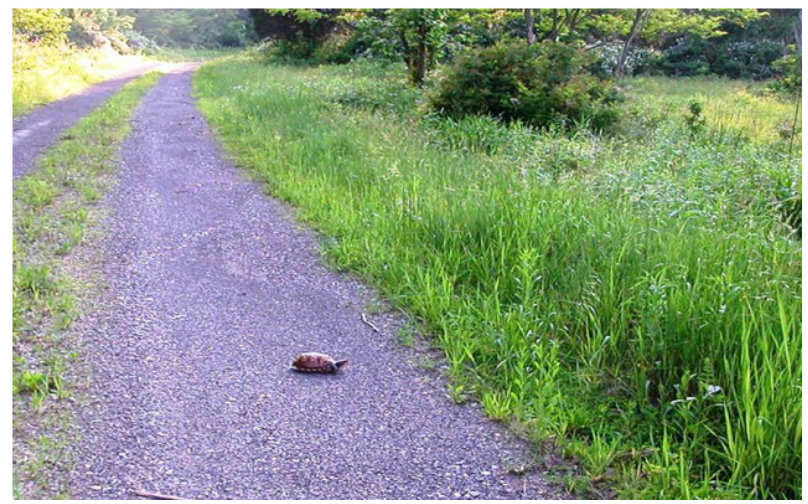

Figure 4. Quarry Rd. Letterkenny Army Depot, Chambersburg, Franklin County, Pennsylvania. Photographed by P.R. Delis.

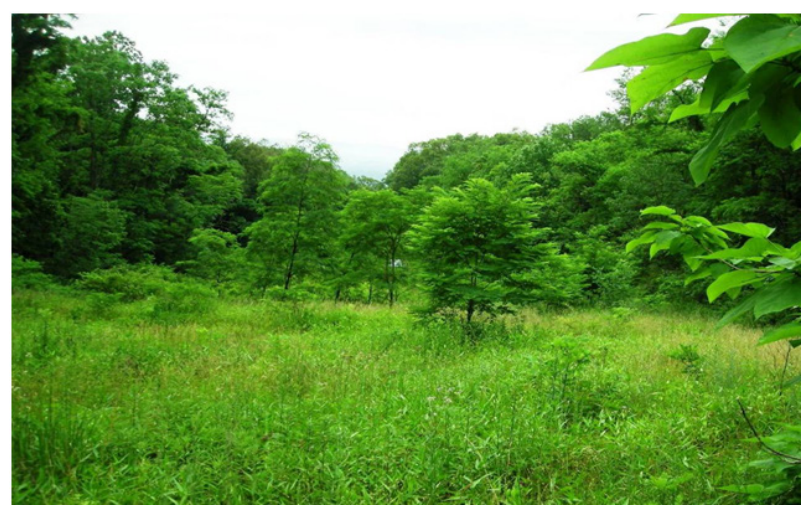

Figure 5. Fire Break. Letterkenny Army Depot, Chambersburg, Franklin County, Pennsylvania. Photographed by P.R. Delis.

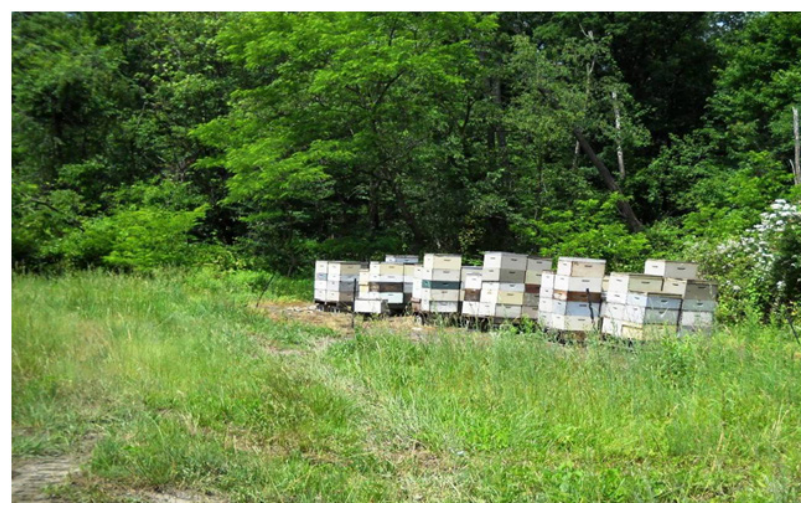

Figure 6. Forestry Cabin-Open. Letterkenny Army Depot, Chambersburg, Franklin County, Pennsylvania. Photographed by P.R. Delis. 
most western and least anthropogenically-impacted portion of the buffer area, which represented major habitat features of Zone 2. The greatest distance among all of the study sites was $6.3 \mathrm{~km}$ between the most northern and southern sites.

1. Bombing Range 1 (BR-1) (Figure 1 ) was a 0.5 ha mountain site of sloping grassland with four cover boards. At 390 m, BR-1 was the highest elevation site.

2. Bombing Range 2 (BR-2) (Figure 2) was a 2 ha mountain site of sloping grassland with eight cover boards.

3. Log Cabin-Open (LCO) (Figure 3) was a 0.5 ha topographically intermediate site of old field with four cover boards.

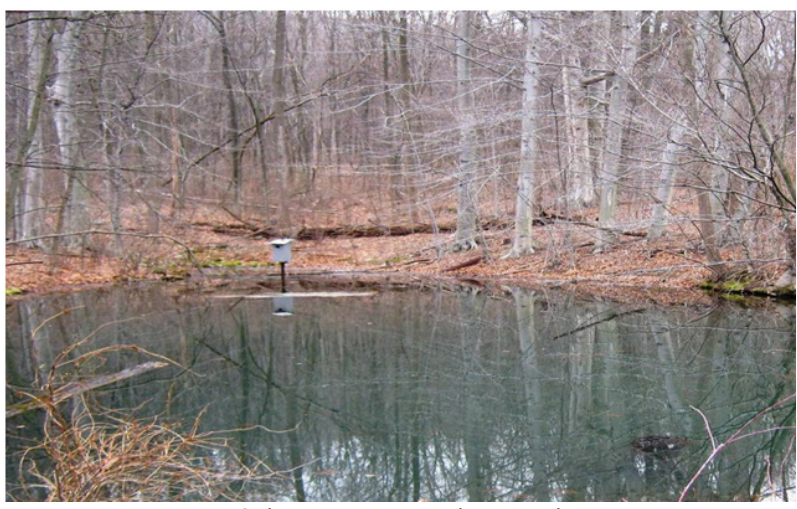

Figure 7. Forestry Cabin-Forest Pond. Letterkenny Army Depot, Chambersburg, Franklin County, Pennsylvania. Photographed by P.R. Delis.

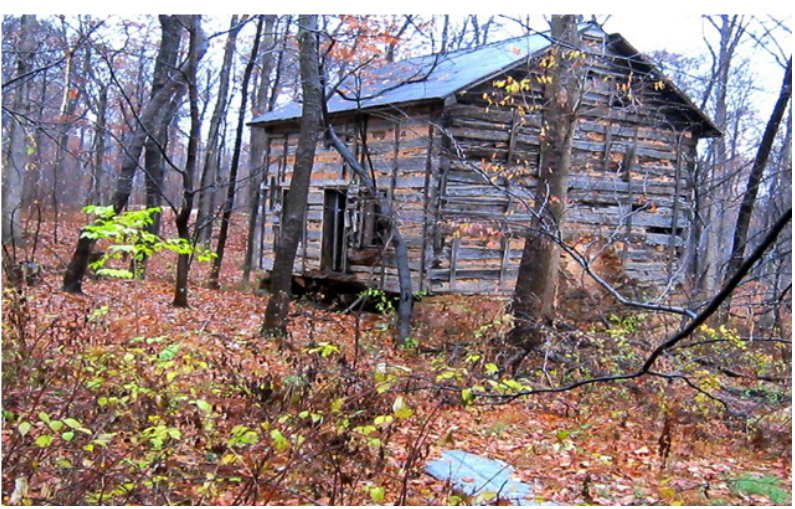

Figure 8. Log Cabin-Forest. Letterkenny Army Depot, Chambersburg, Franklin County, Pennsylvania. Photographed by P.R. Delis.

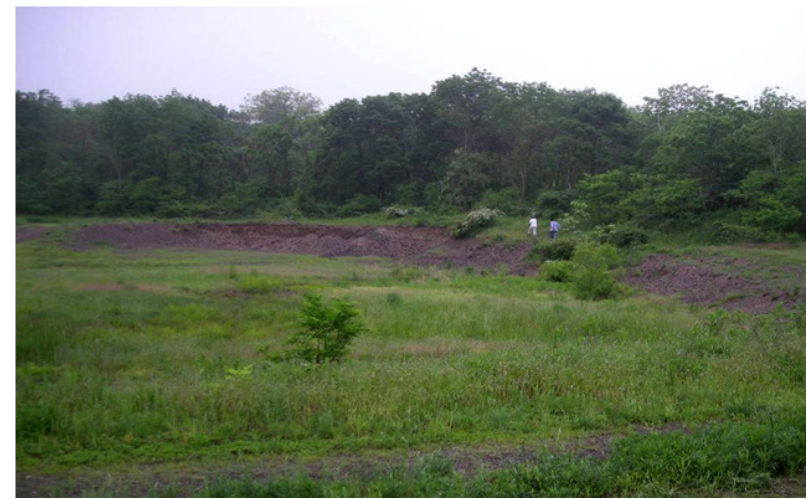

Figure 9. Quarry. Letterkenny Army Depot, Chambersburg, Franklin County, Pennsylvania. Photographed by P.R. Delis.
4. Quarry Road (QR) (Figure 4) was a 0.5 ha valley site of old field-thicket interface with four cover boards.

5. Fire Break (OFB) (Figure 5) was a 1.0 ha mountain site of linear old field approximately $45 \mathrm{~m}$ wide between two forests as a fire break with eight cover boards.

6. Forestry Cabin-Open (FCO) (Figure 6) was a 0.25 ha valley site of open forest plot surrounded by closed canopy forest with four cover boards.

7. Forestry Cabin-Forest Pond (FCFP) (Figure 7) was a 0.05 ha valley site of permanent pond located within a closed-canopy mixed deciduous hardwood forest and bordering FCO with one cover board. Forest Cabin-Forest Pond was the most southern site and also the lowest elevation $(200 \mathrm{~m})$.

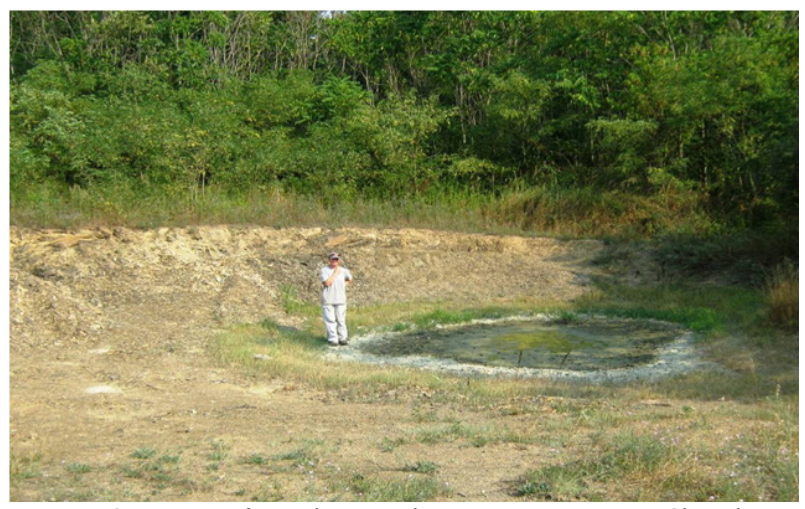

Figure 10. Farmers' Pond. Letterkenny Army Depot, Chambersburg, Franklin County, Pennsylvania. Photographed by P.R. Delis.

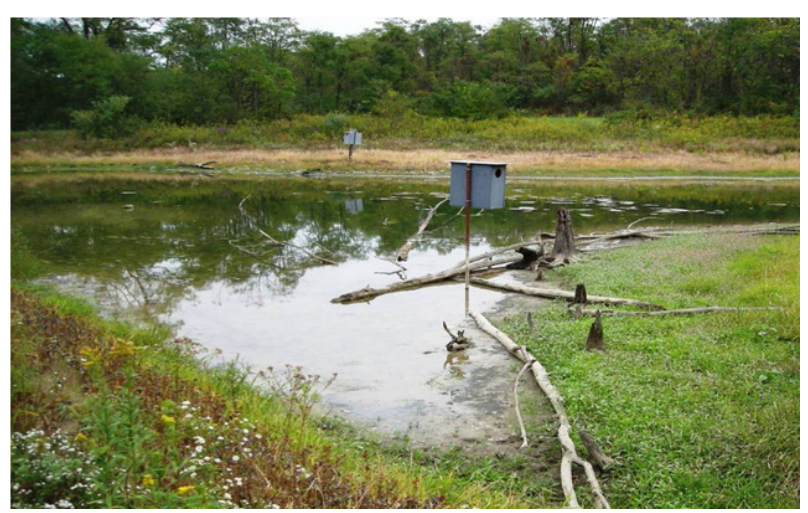

Figure 11. Walley's Pond. Letterkenny Army Depot, Chambersburg, Franklin County, Pennsylvania. Photographed by P.R. Delis.

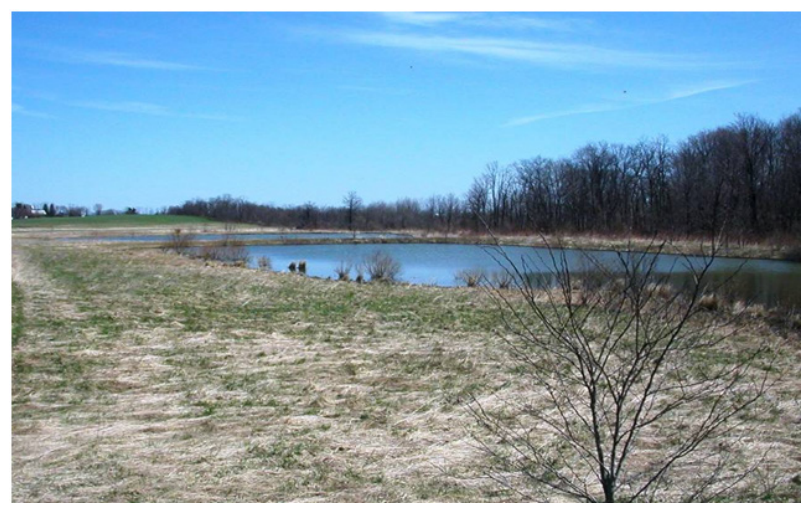

Figure 12. Entrance Ponds. Letterkenny Army Depot, Chambersburg, Franklin County, Pennsylvania. Photographed by P.R. Delis. 


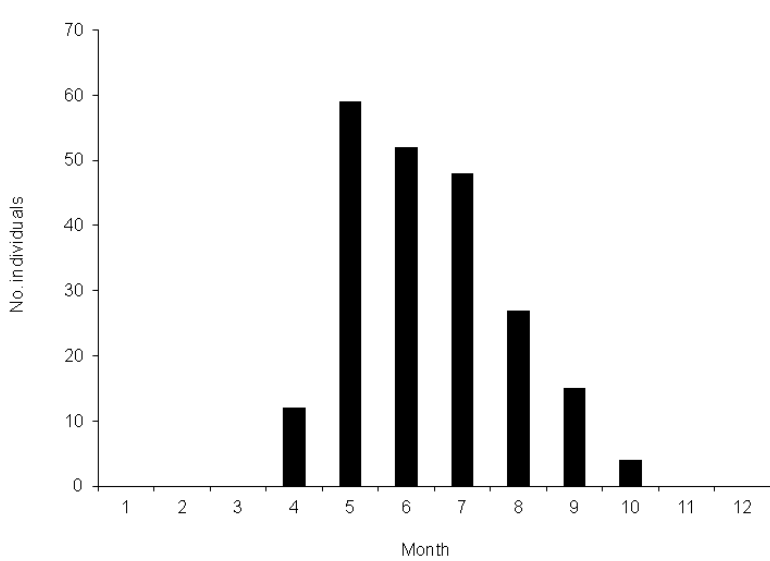

Figure 13. Monthly distribution of captures of 217 individuals of eight species of snakes from Letterkenny Army Depot, Chambersburg, Franklin County, Pennsylvania, during 2008-2011.

8. Log Cabin-Forest (LCF) (Figure 8) was a 0.05 ha topographically intermediate site of closed-canopy mixed deciduous hardwood forest with four cover boards.

9. Quarry (Q) (Figure 9) was a 0.75 ha valley site that was a gravel pit bordered by a thicket on the other side of QR. Those two sites were separated by a 100 $\mathrm{m}$ straight-line distance. Two cover boards were set at Q.

10. Farmers' Pond (FP) (Figure 10) was a 0.05 ha valley site was a gravel pit located in an agricultural field and bordered on one side by mixed deciduous hardwood forest. Three cover boards were set at this site.

11. Walley's Pond (WP) (Figure 11) was a 0.75 ha valley site that was a permanent exposed pond surrounded by mixed deciduous hardwood forest. Three cover boards were set at this site.

12. Entrance Ponds (EP) (Figure 12), the most northern site, was a valley site comprised of two approximately 0.50 and 0.75 ha adjoining spring-fed permanent agricultural ponds which were roughly rectangular and in line with each other. Eight cover boards were set at this site.

\section{METHODS}

Cover boards consisted of 1.0-1.2 X 2.0-2.5 m corrugated metal sheets. We checked cover boards for snakes once each month during April-October 2008-2011. The above methodology served as the standardized survey

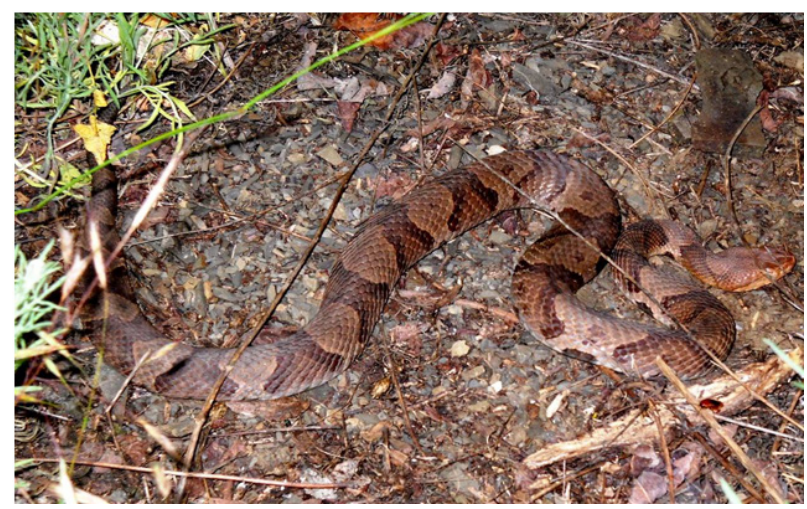

Figure 14. An adult Copperhead (Agkistrodon contortrix) found under a cover board at Bombing Range-1 on 1 June 2010. Photographed by P.R. Delis.

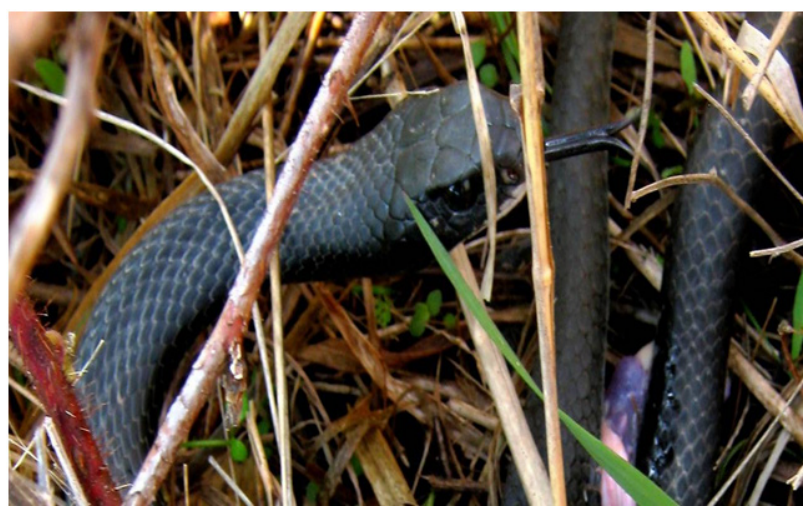

Figure 15. A North American Racer, Coluber constrictor, found in copula beside a cover board 25 April 2011. Both snakes were recaptured individuals. Photographed by P.R. Delis.

method for the collection of data used in the analysis of relative abundance and activity patterns. Additionally, opportunistic visits were made in which snakes captured from under the aforementioned cover boards, other covers, or found in the open, were marked, and in the case of females, palpated, in the field in an effort to estimate clutch size. Most visits occurred on cool mornings or later in the afternoon as air temperatures began to cool. Captured snakes were immediately processed and afterwards coaxed to return under the cover board of capture. For each snake, sex was determined by caudal palpation, and body size as snout-vent length (SVL) and tail length $(T L)$ were measured to the nearest $0.1 \mathrm{~cm}$ with the use of a tape measure. We considered total body length (TBL) the sum of the SVL plus the TL for a given individual. Snakes that were smaller than $30.0 \mathrm{~cm}$ TBL were marked with a scale notch on the ventral aspect of the tail using surgical scissors which served as a cohort mark. All other snakes were individually marked with an AVID PIT (passive integrated transponder) tag subcutaneously.

Assemblage structure was assessed using the percent of total individuals captured from a given site that were species X. We used Microsoft Excel 2007 software to

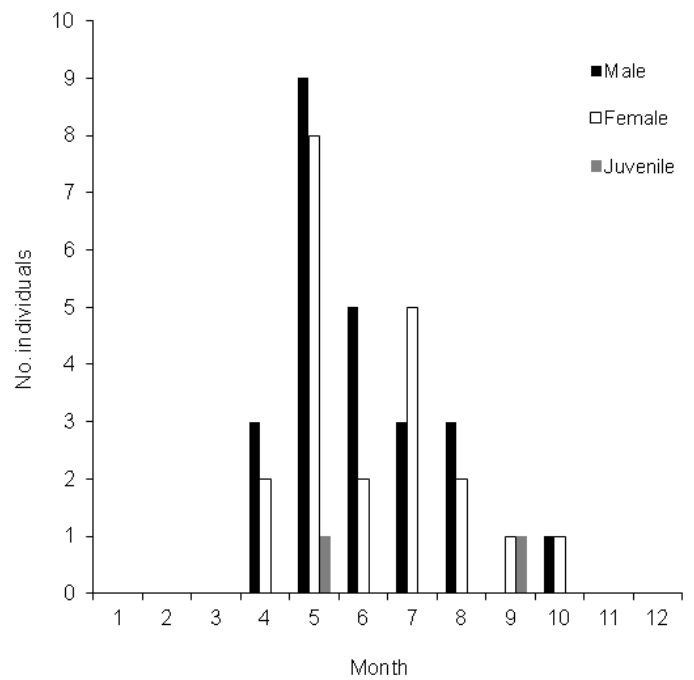

Figure 16. Monthly distribution of captures of male $(n=24)$, female $(n=21)$, and juvenile $(n=2)$ North American Racers (Coluber constrictor) from Letterkenny Army Depot, Chambersburg, Franklin County, Pennsylvania, during 2008-2011. A large individual of unknown status was captured in October. 


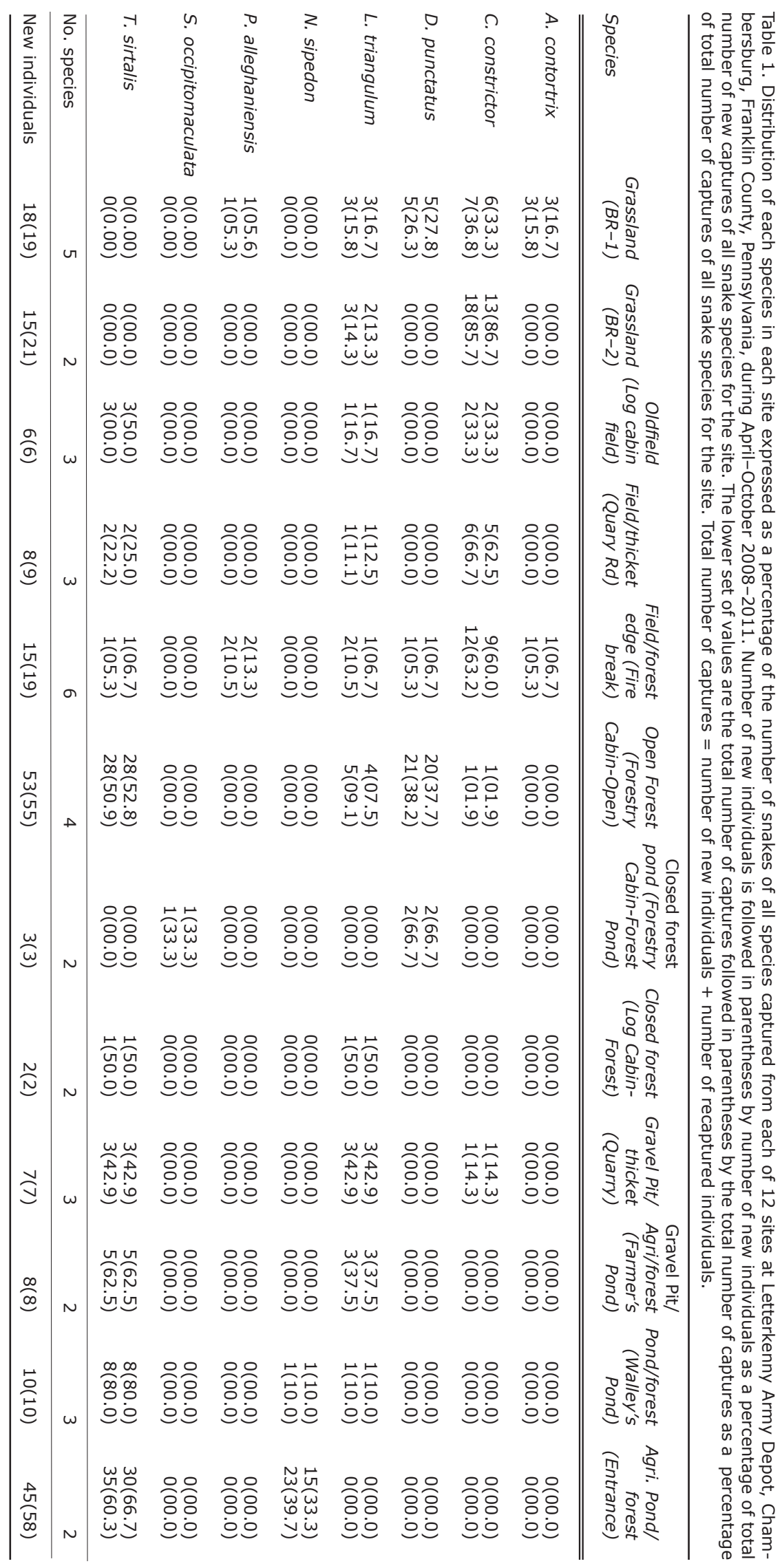


calculate sample statistics and to run statistical tests. Statistical significance was recognized at $p<0.05$. Bar graph sample sizes are based on standardized samplings, whereas scatterplot sample sizes, always larger, contained all methods of sampling including opportunistic surveys. With sufficient sample sizes, this latter dataset was used to estimate growth rates based on likely cohort groupings by month. Voucher specimens of all species encountered in this study, except for the single Red-bellied Snake (Storeria occipitomaculata) which was marked and released, are deposited in the section of Zoology and Botany at the State Museum of Pennsylvania, Harrisburg, Pennsylvania.

\section{RESULTS}

Assemblage Structure - We detected eight snake species under cover boards during standardized searches (Table 1). The highest numbers of species were found in open habitats, such as a field/forest edge site ( $n=$ $6)$, a grassland site $(n=5)$, and an open forest site ( $=4$ ) (Table 1 ). Highly uneven assemblages, where one species constituted $>60 \%$ of captures occurred in sites with more than two species but typified sites with only two species. Exceptionally, the closed forest site of LCF had two species, each at $50 \%$; however, with only two captures. Among the open habitat sites, the North American Racer dominated all but one site, the LCO which was a small overgrown field surrounded by forest on three sides. Open forest, dominated by the common Gartersnake, was also inhabited by the highest number of new captures, whereas the fewest species and individuals were captured in closed forest. Disturbed habitat with gravel pits were less productive for numbers of individuals than were permanent ponds, either surrounded by forest or agricultural fields and forest despite both habitats having been represented by three species among them (Table 1).

Seasonal Activity - We detected snakes under cover in all seven months of our study. The fewest numbers of species were found in April and October, with only three species in each of those months. Between five and six species were detected in the intervening months. We found the Copperhead and the Red-bellied Snake each only in May, the North American Racer in all seven months, and the remaining species in six months. The monthly distri-

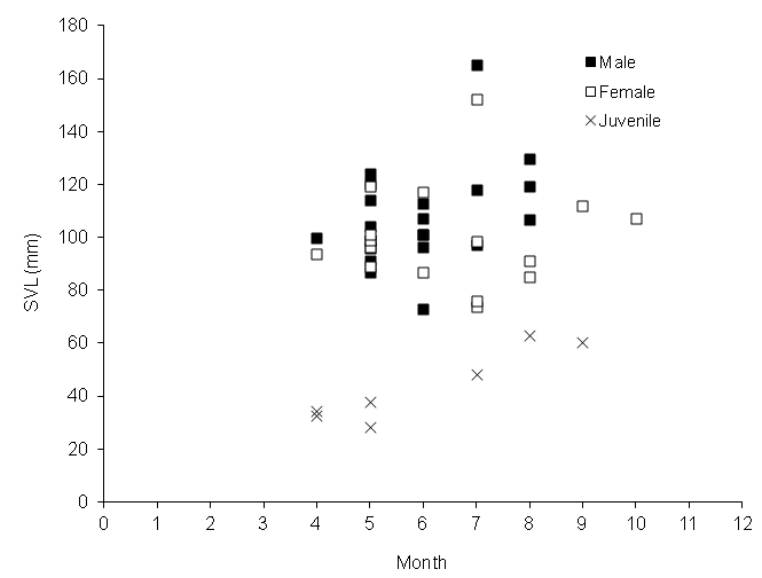

Figure 17. Monthly distribution of body sizes of male $(n=21)$, female $(n=16)$, and juvenile $(n=8)$ North American Racers (Coluber constrictor) from Letterkenny Army Depot, Chambersburg, Franklin County, Pennsylvania, during 2008-2011. Data represent new individuals from standardized and opportunistic captures. bution of all captures for all species combined was unimodal in shape, with $73 \%$ of all captures having occurred during May-July (Figure 13). The spring-summer peak in snake captures was overlapped by May and September peaks in rainfall volume and partially overlapped the two hottest months of July and August as determined by long-term weather data from Chambersburg.

\section{SPECIES ACCOUNTS}

Agkistrodon contortrix (Linnaeus, 1766) - With four new and four total captures, the Copperhead (Figure 14) occurred in two open habitats near forest (Table 1). We found two adults together at BR-1 on 27 August 2009, a single adult under the same cover board on 1 June 2010, and a third adult under cover at OFB on 23 August 2011. All individuals were approximately $60-80 \mathrm{~cm}$ TBL.

Coluber constrictor Linnaeus, 1758 - With 37 new and 47 total captures, the North American Racer (Figure 15) used seven of the 12 sites, where it was most abundant in open habitats, especially BR-1 and BR-2, which were the largest grasslands and separated by forest. In turn, this species was least likely to be found in shaded habitat (Table 1). Adults of this species could be very large, with the largest male having measured $165.1 \mathrm{~cm} \mathrm{SVL}$ and $200.7 \mathrm{~cm}$ TL. Mean adult body sizes were calculated for 18 males $(108.1+20.2 \mathrm{~cm} \mathrm{SVL}$; range $=73-165.1)$ and 15 females $(101.2+19.3 \mathrm{~cm} \mathrm{SVL}$; range $=74-152.4)$. A single juvenile (28.4 cm SVL) was captured at FCO and another juvenile (60.2 cm SVL) was captured at BR-2.

Seasonal activity of the North American Racer ranged from April-October, with most individuals encountered in May (Figure 16). The overall seasonal activity of this species was unimodal in pattern; however, there may have been differences in male and female activity patterns. The seasonal activity pattern in males was unimodal, whereas that of females was possibly bimodal with a smaller second peak in July (Figure 16). We found juveniles during May-September but with too few individuals observed to identify a seasonal activity pattern (Figure 16). Among sexually mature adults, a Chi Square revealed no significant difference $(p>0.05)$ from unity in the male:female ratio of standardized captures of new snakes only (1.20:1.00; $\mathrm{n}=33)$, standardized captures of new and recaptured snakes (1.14:1.00) (Figure 16), and of all new snakes from combined standardized and opportunistic captures $(1.31: 1.00)$ (Figure 17). We observed a pair of large adults atop one of the cover boards on 28 May 2009, but they escaped before either individual could be captured. On 25 April 2011, we captured a pair in copula next to a cover board in BR-2. The

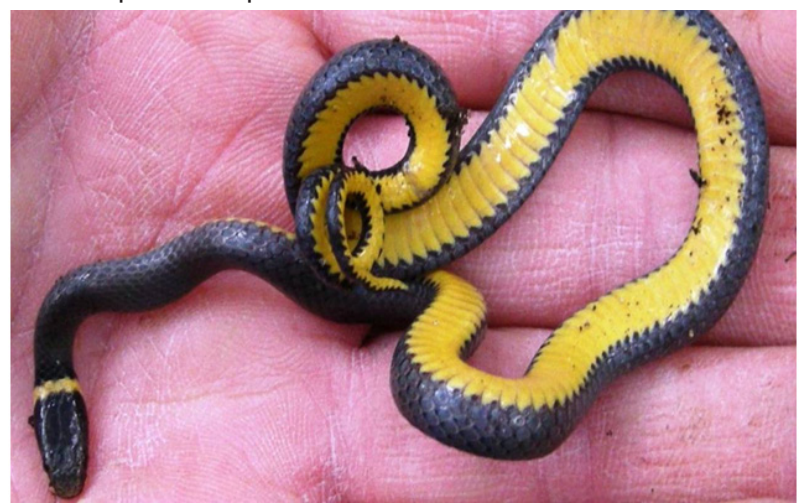

Figure 18. A Ring-necked Snake (Diadophis punctatus) captured at Forestry Cabin-Open, where the species is abundant. Photographed by P.R. Delis. 


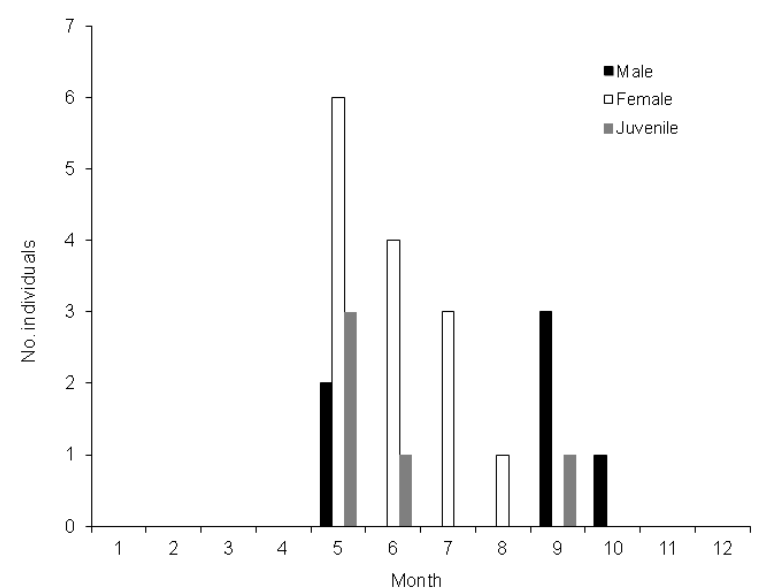

Figure 19. Monthly distribution of captures of male $(n=6)$, female ( $n=14)$, and juvenile $(n=5)$ Ring-necked Snakes (Diadophis punctatus) from Letterkenny Army Depot, Chambersburg, Franklin County, Pennsylvania, during 2008-2011. Four individuals of unknown status were captured in May.

male (119 cm SVL) was larger than the female (107.0 cm SVL).

Including all new finds from standardized trapping and opportunistic captures, gravid females were active in May $(n=3)$ and June $(n=2)$. A recently spent female was under a cover board on 1 July. An $89.2 \mathrm{~cm}$ SVL female that we palpated on 25 May contained 13 eggs. An $99.0 \mathrm{~cm}$ SVL female that we palpated on 28 May 2011 contained 13 eggs. An $87.0 \mathrm{~cm}$ SVL female that we palpated on 3 June 2011 contained 11 eggs.

The smallest individuals, captured in April and May (Figure 17), were presumed to have been individuals hatched the previous September. Based on an estimation of growth rates from presumed size groups (Figure 17), adults of both sexes were probably sexually mature and mated for the first time in their second spring of life at an age of approximately 19-20 months of age (Figure 17). Among adults, body size of males (mean $=107.8+$ $18.8 \mathrm{~cm} \mathrm{SVL}$; range $=73.0-165.1 ; \mathrm{n}=21$ ) and females (mean $=99.9+19.1 \mathrm{~cm} \mathrm{SVL} ;$ range $=74.0-152.4 ; \mathrm{n}=$ 16) were not significantly different in variances (F-test; $p>0.05$ ) or means (t-test; $p>0.05$ ).

Diadophis punctatus (Linnaeus, 1766) - With 28 new and 29 total captures, the Ring-necked Snake (Figure 18) occurred in four sites where it was clearly most abundant in the open forest habitat of FCO (Table 1). We

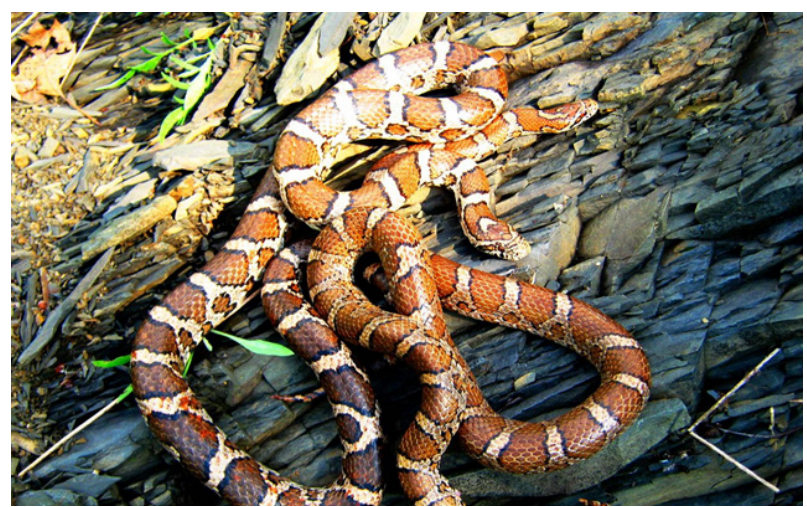

Figure 21. A pair of Milksnakes (Lampropeltis triangulum) found together under cover at Bombing Range-1 on 25 May 2011. Both snakes were new individuals. Photographed by P.R. Delis.

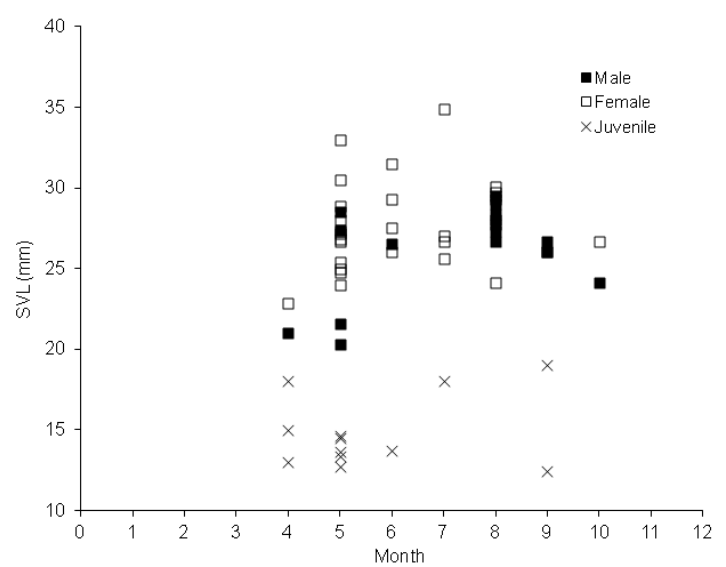

Figure 20. Monthly distribution of body sizes of male $(n=18)$, females ( $n=25)$, and juvenile $(n=12)$ Ring-necked Snakes (Diadophis punctatus) from Letterkenny Army Depot, Chambersburg, Franklin County, Pennsylvania, during 2008-2011. Data represent new individuals from standardized and opportunistic captures.

found two individuals in the adjacent closed canopy FCFP, which bordered the latter site. The few new individuals found at BR-1 (two males, two females, one juvenile) and OFB (one juvenile) were under cover boards close to the forest edge. For all sites combined, mean body sizes were available for six males $(24.6+1.5 \mathrm{~cm}$ SVL; range $=24.1-28.5), 13$ females $(27.8+3.3 \mathrm{~cm} \mathrm{SVL}$; range $=$ $24.1-34.9)$, and five juveniles $(14.8+2.4 \mathrm{~cm}$ SVL; range $=13.3-19.0)$.

Seasonal activity of the Ring-necked Snake ranged from May-October, with most captures having occurred in May (Figure 19). The seasonal activity pattern of this species was unimodal. Among sexually mature adults, a Chi Square revealed no significant difference $(p>0.05)$ from unity in the male:female ratio of standardized captures of new snakes only $(0.57: 1.00 ; n=22)$, standardized captures of new and recaptured snakes $(0.46: 1.00)$ (Figure 19), and of all new snakes from combined standardized and opportunistic captures (0.72:1.00) (Figure 20). Males were active during May-October, especially in September, with what may have been an initial lesser peak in May (Figure 19). Females were active during May-October, especially in May, and were unimodal in their sea-

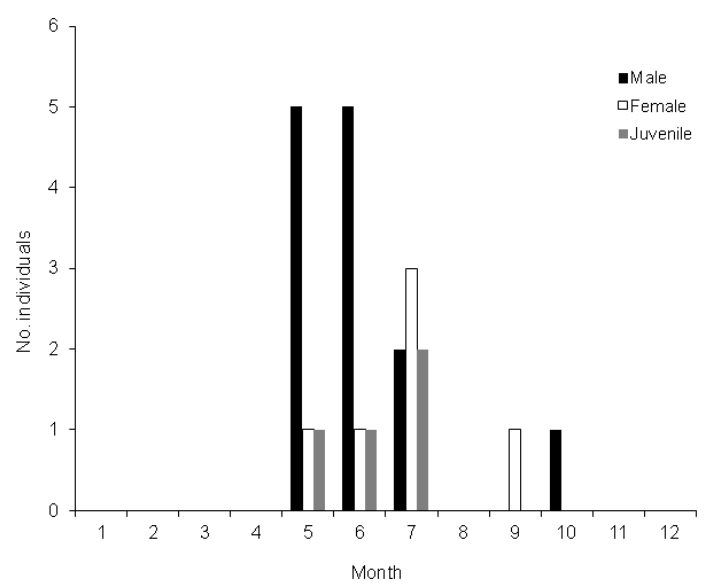

Figure 22. Monthly distribution of captures of male $(n=13)$, females $(n=6)$, and juvenile $(n=4)$ Milksnakes (Lampropeltis triangulum) from Letterkenny Army Depot, Chambersburg, Franklin County, Pennsylvania, during 2008-2011. 
sonal activity pattern (Figure 19). Juveniles were found during May-September but with too few individuals to identify a seasonal activity pattern (Figure 19).

Including all new finds from standardized trapping and opportunistic captures, all seven gravid females were found in May. We found recently spent females under cover boards on 1 June 2010 and 30 July 2008. A 28.9 cm SVL female that we palpated on 25 May 2011 contained five eggs.

The smallest individual seen in September measured $12.4 \mathrm{~cm}$ SVL and had presumably hatched in August (Figure 20). Individuals in April and May having measured up to approximately $15 \mathrm{~cm}$ SVL suggests the narrow range of growth since fall hatching. Estimated growth trajectories were suggestive of sexual maturity by the beginning of their second spring at approximately 20-21 months of age (Figure 20). Mean body size of males $(26.3+2.8 \mathrm{~cm}$ $\mathrm{SVL}$; range $=20.3-29.5 ; \mathrm{n}=18$ ) was $4.7 \%$ smaller than that of females $(27.6+2.9 \mathrm{~cm} \mathrm{SVL}$; range $=22.8-34.9$; $\mathrm{n}=25)$. We detected no significant difference between the variances (F-test; $p>0.05$ ) or means (t-test; $p>$ 0.05 ) of the sexes.

Lampropeltis triangulum (Lacépède, 1789) - With 20 new and 23 total captures, the Milksnake (Figure 21) occurred in ten sites but was not especially common in any of them (Table 1). Apart from FCO in which only a single juvenile North American Racer ( $28.6 \mathrm{~cm} \mathrm{SVL}$ ) was encountered, in the open habitat sites of BR-1, BR-2, Q, LCO, and OFB, which they shared with the North American Racer, the mean adult body sizes were relatively large in six males $(84.4+4.2 \mathrm{~cm} \mathrm{SVL}$; range $=78-89)$ and five females $(73.2+4.8 \mathrm{~cm} \mathrm{SVL}$; range $=67.8-$ 78.1). Elsewhere, in areas in which adult North American Racers were absent, the mean adult body size of four males $(66.3+7.9 \mathrm{~cm} \mathrm{SVL} ; 58-77)$ was relatively small, one female measured $76.5 \mathrm{~cm} \mathrm{SVL}$, and four juveniles ranged $36-44 \mathrm{~cm}$ SVL (mean $=36.7+7.7 \mathrm{~cm} \mathrm{SVL}$ ). A significant difference existed in the means $(t=7.613$; df $=8 ; p=0.0007)$ but not variances $(p>0.05)$ of adult male body size between sites with and without the North American Racer.

Seasonal activity of the Milksnake ranged from MayOctober with most captures having occurred equally during May-July (Figure 22). Seasonal activity of this species was unimodal in pattern. Among sexually mature

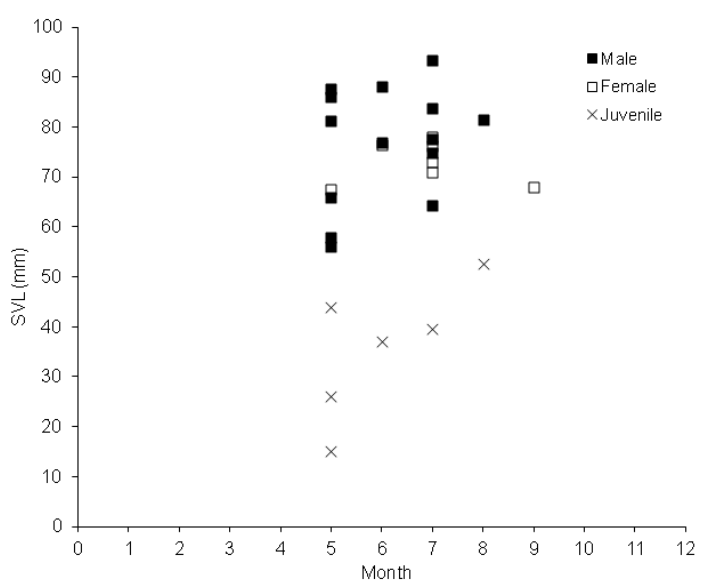

Figure 23. Monthly distribution of body sizes of male $(n=14)$, females $(n=7)$, and juvenile $(n=6)$ Milksnakes (Lampropeltis triangulum) from Letterkenny Army Depot, Chambersburg, Franklin County, Pennsylvania, during 2008-2011. Data represent new individuals from standardized and opportunistic captures. adults, a Chi Square test revealed no significant difference ( $p>0.05)$ from unity in the male:female ratio of standardized captures of new snakes only (1.67:1.00; $\mathrm{n}=16)$, standardized captures of new and recaptured snakes (2.17:1.00) (Figure 22), and of all new snakes from combined standardized and opportunistic captures 2.00:1.00) (Figure 23). Males were active during MayOctober, especially in May and June, and exhibited a unimodal seasonal activity pattern (Figure 22). Females were active during May-September, especially in July, but with too few individuals to be certain of a unimodal pattern to their seasonal activity (Figure 22). We found juveniles during May-July but with too few individuals to identify a seasonal activity pattern (Figure 22).

We found pairs of adult males and females together under cover boards on 25 May 2011 and 3 June 2010. A $78.1 \mathrm{~cm}$ SVL female that we palpated on 1 July 2009 contained 12 eggs.

The smallest individuals ( 15.2 and $26.0 \mathrm{~cm} \mathrm{SVL}$ ) were captured in May (Figure 23), having hatched the previous August or September. New captures of juveniles were scant but suggest sexual maturity being reached sometime in their third fall of life. If so, females would lay eggs for the first time the following summer at approximately 34-35 months of age. Body sizes of males (mean $=76.8+11.6 \mathrm{~cm} \mathrm{SVL} ;$ range $=56.0-93.4 ; \mathrm{n}=$ 14 ) and females (mean $=72.9+4.2 \mathrm{~cm} \mathrm{SVL}$; range $=$ $67.5-78.1 ; n=7)$ differed in variance $(F=7.520, \mathrm{df}=$ $1,13, p=0.010)$ but not mean $(p>0.05)$.

Nerodia sipedon (Linnaeus, 1758) - With 16 new and 24 total captures, the Common Watersnake (Figure 24) occurred exclusively at two open and permanent ponds (Table 1). None occurred at temporary gravel pits or in the closed forest pond at FCFP. For all sites combined, body size measurements were obtained for males (48.0 $+5.1 \mathrm{~cm} \mathrm{SVL}$; range $=39.4-55.0 ; \mathrm{n}=9)$, females $(61.7$ $+7.1 \mathrm{~cm} \mathrm{SVL} ;$ range $=54.4-69.9 ; \mathrm{n}=4)$ and three juveniles (28.0, 29.2, $38.3 \mathrm{~cm} \mathrm{SVL)}$.

Seasonal activity of the Common Watersnake ranged from April-September, with most captures occurring in June (Figure 25). Seasonal activity of this species was unimodal in pattern. Among sexually mature adults, a Chi Square revealed no significant difference $(p>0.05)$ from unity in the male:female ratio of standardized captures of new snakes only (2.25:1.00; $n=13)$, standardized captures of new and recaptured snakes (2.00:1.00) (Figure 25), and of all new snakes from combined standardized and opportunistic captures (1.80:1.00) (Figure 26). Males were active during April-September, especially in

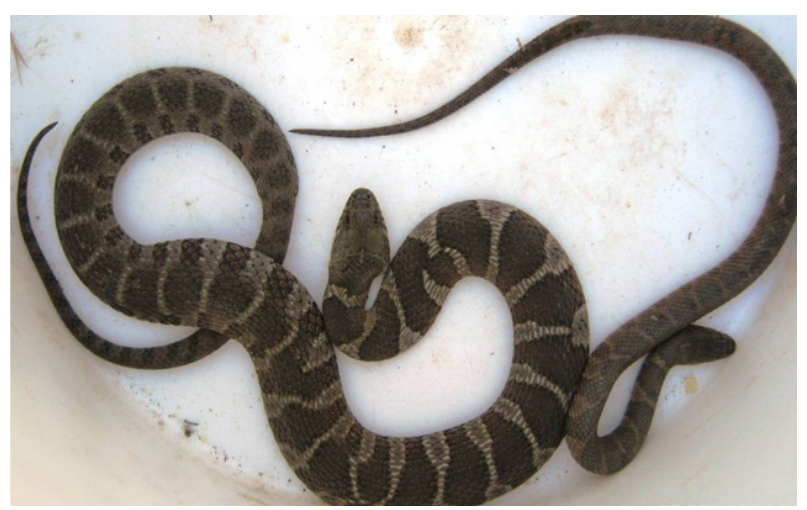

Figure 24. A recaptured male and new juvenile Common Watersnake (Nerodia sipedon) opportunistically captured at Walley's Pond on 30 June 2011. Photographed by P.R. Delis. 
June, and exhibited a unimodal seasonal activity pattern (Figure 25). Females were active during June-August, especially in July, and exhibited a unimodal seasonal activity pattern (Figure 25). We found juveniles in May and July but too few individuals were observed to identify a seasonal activity pattern (Figure 25).

We found a $47 \mathrm{~cm}$ SVL male with a $67.0 \mathrm{~cm}$ SVL female under the same cover board on 31 July 2011. The smallest individuals ( 28.0 and $29.2 \mathrm{~cm} \mathrm{SVL}$ ) were found in June and July, respectively, and likely represented snakes born the previous September (Figure 26). Mean body size of males $(48.0+5.1 \mathrm{~cm} \mathrm{SVL}$; range $=39.4-$ $55.0 ; \mathrm{n}=9$ ) was significantly smaller $(\mathrm{t}=-4.2116 ; \mathrm{df}=$ $12 ; \mathrm{p}<0.000)$ than that of females $(61.7+7.1 \mathrm{~cm} \mathrm{SVL}$; range $=54.4-69.9 ; n=5$ ).

Pantherophis alleghaniensis (Holbrook, 1836) - With three new and three total captures, the Eastern Rat Snake (Figure 27) was present at two sites (BR-1 and OFB) near the edge of fields bordering forest (Table 1 ). The three males captured in June (106.0 and 125.0 $\mathrm{cm} \mathrm{SVL})$ and July $(125.7 \mathrm{~cm} \mathrm{SVL})$ were not recaptured during this study. The smallest individual Eastern Rat Snake seen in our study was a juvenile male $55.5 \mathrm{~cm}$ SVL that was encountered resting on a paved road on 3 August 2012. Mean body size of males $(122.6+12.1 \mathrm{~cm}$ $\mathrm{SVL}$; range $=103.0-140.3 ; \mathrm{n}=9$ ) was $1.0 \%$ larger than that of females $(119.7+14.1 \mathrm{~cm} \mathrm{SVL}$; range = 106.7$136.0 ; n=4)$. No significant difference was detected in the mean $(p>0.05)$ or variance $(p>0.05)$ of adult body sizes between the sexes.

Storeria occipitomaculata (Storer, 1839) - A single Red-bellied Snake (Figure 28) was found during our survey, at FCFP on 25 May 2008. This individual (26.5 $\mathrm{cm}$ SVL) was gravid and was not recaptured during this study.

Thamnophis sirtalis (Linnaeus, 1758) - With 81 new and 86 total captures, the Common Gartersnake (Figure 29) was found at nine sites and in most habitat types (Table 1). It was overwhelmingly most abundant along the margins of exposed ponds (Table 1 ). We encountered this species least often in closed canopy forest and grasslands (Table 1). Exclusive of FCO in which only a single juvenile North American Racer (28.6 cm SVL) was encountered, sites shared with the North American Racer were comprised of only a few large females $(64.3+9.3$

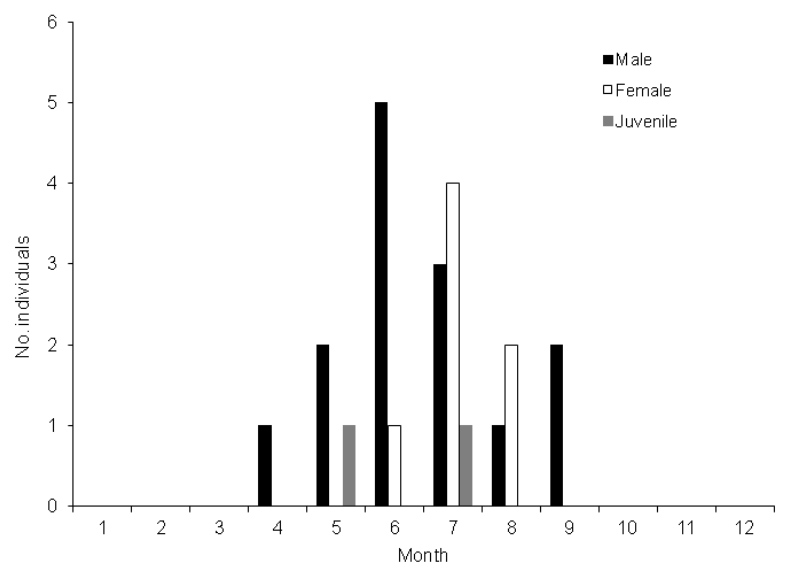

Figure 25. Monthly distribution of captures of male $(n=14)$, female $(n=7)$, and juvenile $(n=2)$ Common Watersnakes (Nerodia sipedon) from Letterkenny Army Depot, Chambersburg, Franklin County, Pennsylvania, during 2008-2011. One individual of unknown status was captured in July. $\mathrm{cm} \mathrm{SVL} ;$ range $=52.0-78.1 ; \mathrm{n}=5)$ and a few juveniles $(19.0+5.5 \mathrm{~cm} \mathrm{SVL}$; range $=13.4-26.0 ; \mathrm{n}=4)$. Mean body size of female Common Gartersnakes (54.1 + 7.7 $\mathrm{cm}$ SVL; range $=40.0-70.3 ; \mathrm{n}=35$ ) from standardized captures in non-racer sites was significantly smaller $(\mathrm{t}=$ $2.7145 ; \mathrm{df}=38$; $\mathrm{p}=0.005$ ) than that of females captured in North American Racer-rich areas.

Seasonal activity of the Common Gartersnake ranged April-September, with most captures having occurred in June (Figure 30). Seasonal activity of this species was unimodal in pattern. Among sexually mature adults, a Chi Square revealed significant differences $(p<0.05)$ from unity in the male:female ratio of standardized captures of new snakes only $(0.43: 1.00 ; n=57 ; \mathrm{X} 2=$ $9.281 ; p<0.001)$, standardized captures of new and recaptured snakes $(0.39: 1.00 ; X 2=12.250 ; p<0.001)$ (Figure 30 ), and of all new snakes from combined standardized and opportunistic captures $(0.53: 1.00 ; \mathrm{X} 2=$ $13.172 ; p<0.001$ ) (Figure 31). Males were active during April-September, but most active in April, June, and September, and may have exhibited a bimodal seasonal activity pattern (Figure 30). Females were active during April-September, especially in July, and exhibited a unimodal seasonal activity pattern (Figure 30). We found juveniles during May-September, especially in August, and they exhibited a unimodal seasonal activity pattern (Figure 30).

The numbers and monthly distribution of juveniles encountered under cover were sufficient to indicate a peak in cover board use by juveniles in August (Figure 30), coinciding with the appearance of neonates (Figure 31). Among breeding adults, under cover boards, a male and female were found together on 7 May 2010, one male and two females on 25 May 2011, one male and three females on 1 June 2010 and 17 June 2011, and a male and female on 24 September 2010. From standardized trapping, the percentage of gravid females in each month was $77.8 \%$ in May, $92.9 \%$ in June, and $58.8 \%$ in July. Including all new finds from standardized trapping and opportunistic captures, 46 females were found to have been gravid during May-July. No spent females were found. The litter size $($ mean $=15.3+6.1 ;$ range $=$ $6-29 ; n=27$ ) and snout-vent length (mean $=54.3+7.5$ $\mathrm{cm} \mathrm{SVL}$; range $=39.0-70.3 ; \mathrm{n}=27$ ) were positively and significantly related to one another (Figure 32 ).

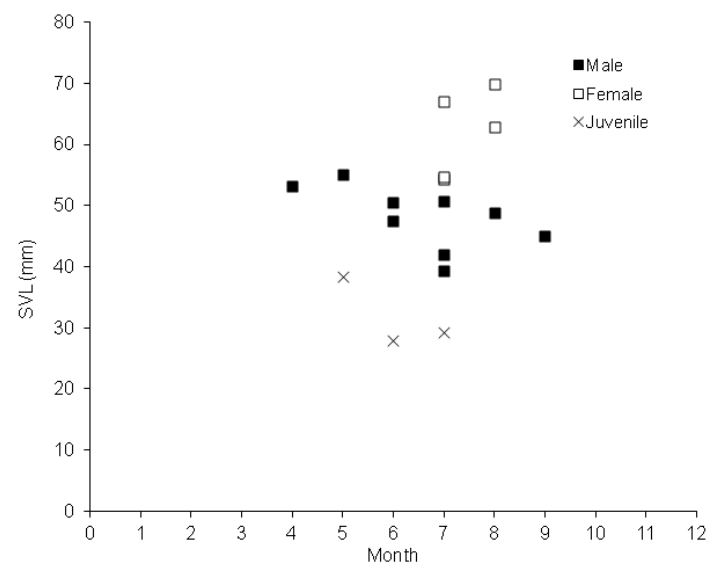

Figure 26. Monthly distribution of body sizes of male $(n=9)$, female $(n=5)$, and juvenile $(n=3)$ Common Watersnakes (Nerodia sipedon) from Letterkenny Army Depot, Chambersburg, Franklin County, Pennsylvania, during 2008-2011. Data represent new individuals from standardized and opportunistic captures. 
The smallest individual measured $13.0 \mathrm{~cm}$ SVL in August (Figure 31), and the distribution of juvenile body sizes in August was suggestive of parturition beginning in July. Growth trajectories were suggestive of rapid maturity in males (ca. 12 months) and females (ca. 14-15 months). Thus, newly-mature individuals of both sexes could reproduce for the first time during their second fall of life, and for females young could be first produced at an age of 23-34 months of age. Mean body size of males $(38.9+7.0 \mathrm{~cm} \mathrm{SVL}$; range $=27.5-52.2 ; \mathrm{n}=29)$ was significantly smaller $(t=-7.0085 ; d f=63 ; p<0.000)$ than that of females $(54.1+8.9 \mathrm{~cm} \mathrm{SVL}$; range $=38.6-$ $78.1 ; \mathrm{n}=64)$.

\section{DISCUSSION}

Species Composition - We recorded eight species of snakes under cover boards. The species list of this study differed slightly from that of a previous study by Delis et al. (2010) which also recorded eight snake species during 2002-2003. Only one Red-bellied Snake was detected among the 190 new captures and 217 total captures of this study and was not detected earlier by Delis et al. (2010), which underscored the importance of long-term monitoring of rare or secretive species. The cover boards in this study failed to detect the Eastern Ribbonsnake, Thamnophis sauritus (Linnaeus, 1766), which was represented by a single capture of an adult at WP in 2003 (Delis et al. 2010). The dearth of these species despite sampling in multiple sites of acceptable habitats leads us to conclude that the Red-bellied Snake and Eastern Ribbonsnake were actually rare in Zone 2 of LEAD. These findings corroborate earlier findings of the uncommonness of both species in this part of Pennsylvania, as well as that of the Eastern Ribbonsnake generally (Hulse et al., 2001). Neither this study nor that of Delis et al. (2010) detected the DeKay's Brownsnake, Storeria dekayi (Holbrook, 1836), Eastern Hog-nosed Snake Heterodon platirhinos, (Latreille, 1801), Smooth Green Snake, Opheodrys vernalis (Harlan, 1827), Common Wormsnake, Carphophis amoenus (Say, 1825), and the Timber Rattlesnake, Crotalus horridus (Linnaeus, 1758), which have been recorded in Franklin County (Hulse et al., 2001; Meshaka and Collins, 2009). Except for the Timber Rattlesnake, these species are either uncommon in the region or in the state generally (Hulse et al., 2001). The Timber Rattlesnake and the Eastern Hognosed Snake have been seen in Zone 2 by LEAD field personnel and Pablo Delis, respectively, but uncommon-

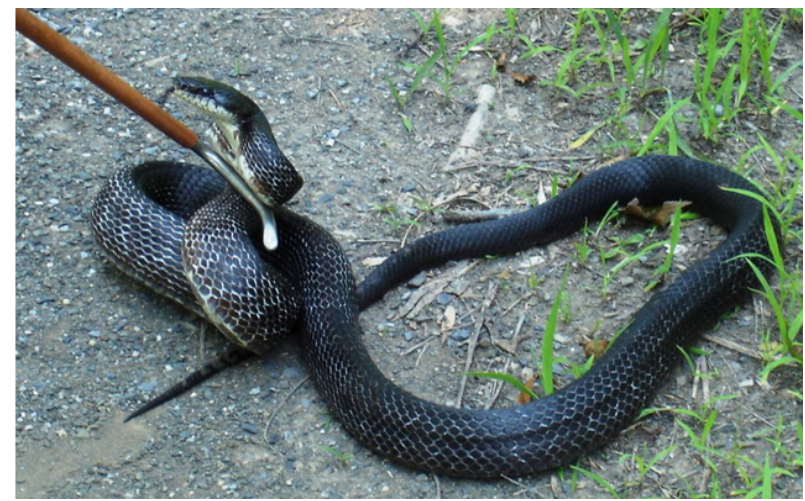

Figure 27. An adult Eastern Rat Snake (Pantherophis alleghaniensis) encountered near the entrance to the Letterkenny Army Depot, Chambersburg, Franklin County, Pennsylvania, on the morning of 27 July 2007. Photographed by P.R. Delis. ly. Thus, apart from the Timber Rattlesnake and Eastern Hog-nosed Snake, it would appear that the unrecorded species were rare if present.

Assemblage Structure - As noted elsewhere in the Northeast, the North American Racer can dominate grassland snake assemblages, especially large ones (Kjoss and Litvaitis, 2001; Meshaka et al., 2009). In larger fields, such as BR-1, BR-2, QR, and OFB, the North American Racer was the dominant component of the assemblage. In light of its association with moist substrates, the Ring-necked Snake seemed unlikely to have been as numerous in BR-1 had the cover boards not been as close to the forest edge. The same would have been true for the Ring-necked Snake and the Eastern Rat Snake at OFB despite the North American Racer's disproportionately high frequency of capture there. Not surprisingly, forest habitat was less utilized by the North American Racer, and few species and individuals colonized the closed canopy forest. To that end, habitats of exposed ponds near forest and open canopy forest may have served to protect the Common Gartersnake from what is probably their main predator, the North American Racer. In these habitats, the Common Gartersnake, in turn was the dominant component, where it outnumbered the Common Watersnake and Ring-necked Snake, respectively. In the grassland systems in western Pennsylvania studied by Meshaka et al. (2009), the North American Racer was absent, and the Common Gartersnake was the dominant species.

Numerically, the Milksnake appeared only slightly less numerous in the presence of the North American Racer than did either the Ring-necked Snake (away from edges) or Common Gartersnake. Yet, both the Common Gartersnake and the Eastern Milksnake seemingly responded to "North American Racer-rich" assemblages with larger body sizes than in sites where they were free of their potential predator. A similar response to the North American Racer in Northeast grasslands was detected in the Common Gartersnake (Kjoss and Litvaitis, 2001). Meshaka et al. (2009) did not find the Common Gartersnake in a site where the North American Racer was abundant; however, only adult Gray Ratsnakes, (Pantherophis spiloides Duméril, Bibron \& Duméril, 1854), two large Eastern Hog-nosed Snakes, one Ring-necked Snake, and adult Timber Rattlesnakes were detected at that site. Findings of this study corroborate earlier findings (Kjoss and Litvaitis, 2001; Meshaka et al., 2009) that northeastern grassland snake assemblage structures that in-

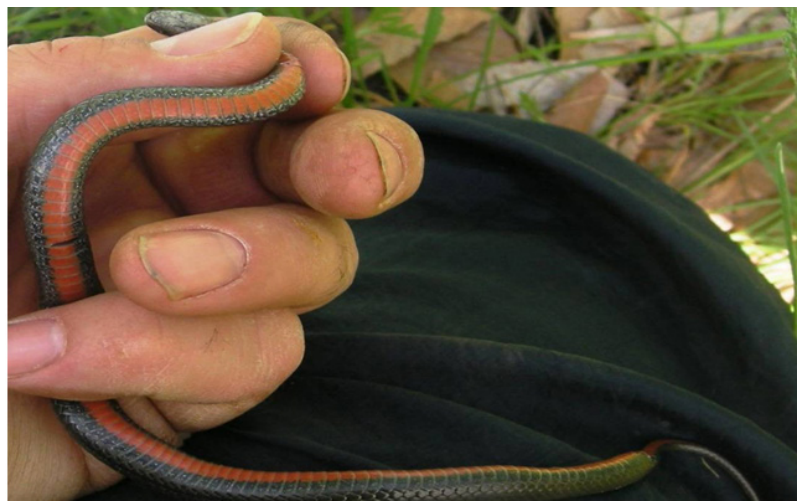

Figure 28. The single Red-bellied Snake (Storeria occipitomaculata) found in this study, a gravid $25.5 \mathrm{~cm}$ SVL female found under a cover board at Forestry Cabin-Pond on 25 May 2008. Photographed by P.R. Delis. 
clude the North American Racer are remarkably different from those in the central plains where the Eastern Yellow-bellied Racer (C. c. flaviventris, Say, 1823) was found to include fewer snakes in its diet (Fitch, 1999) than its eastern counterpart (Uhler et al., 1939; Mitchell, 1994, Palmer and Braswell, 1995).

The species list of snakes for our study in LEAD was typical of the regional fauna, which was comprised of ubiquitous species and species considered to be rare in the state or this region of the state. Few individuals and species were recorded in closed-canopy forest. The Common Gartersnake occurred in more kinds of habitats than any other species. As in other northeastern grasslands, the North American Racer as a dominant component apparently exerted pressure on the assemblage composition, its structure, and the demographic features of some of its members. Most notably, the Common Gartersnake was either absent or rare, and like somewhat diminished populations of the Milksnake in those circumstances, seemed to have larger adult body sizes of females and males, respectively.

Seasonal Activity and Sex Ratios - During the AprilOctober sampling period ,the LEAD snake assemblage was detectable in the highest numbers during May-July, with a May peak. At Powdermill Natural Reserve (PNR), Pennsylvania, in the colder climate of southwestern Pennsylvania, snake activity peaked in June and July, with slightly more individuals detected in June (Meshaka, 2010). In Erie County of northwestern Pennsylvania, activity of a snake assemblage containing five species was relatively high during April-September but highest in June (Gray, 2011). Unlike Meshaka's (2010) study, where one snake, the Red-bellied Snake, occurred in disproportionately higher numbers than in LEAD, two species in Gray's (2010) study, the Dekay's Brownsnake (S. dekayi, Holbrooke, 1836) and the Short-headed Gartersnake (T. brachystoma, Cope, 1892) did not occur at LEAD, and the Red-bellied Snake was found in disproportionately low numbers. An Ohio snake assemblage exhibited a bimodal seasonal activity pattern, having initially peaked during May-June and again in August (Meshaka et al., 2009). A southern Everglades snake assemblage, subject to a strongly bimodal rainy season, responded with a bimodal activity season of May-June and October (Dalrymple et al., 1991). Climatic and latitudinal differences as well as assemblage composition must be taken into consideration when interpreting these conspicuous differences in assemblage activity patterns among sites.

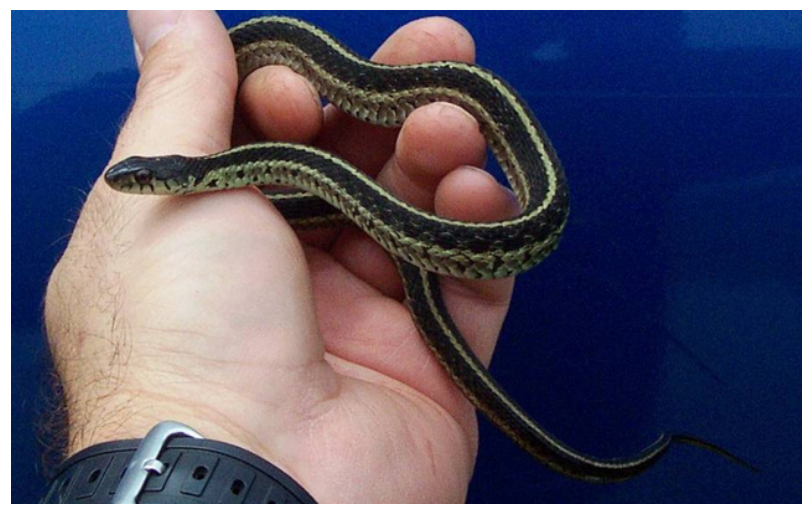

Figure 29. A Common Gartersnake (Thamnophis sirtalis) found at the Letterkenny Army Depot, Chambersburg, Franklin County, Pennsylvania, on the morning of 4 February 2000. Photographed by P.R. Delis.
The five species for which adequate samples were available at LEAD exhibited single peaks in their activity patterns: May (North American Racer, Ring-necked Snake), May-July (Milksnake), and June (Common Watersnake, Common Gartersnake). The seasonal activity mode by LEAD species was generally consistent with populations of those species from surrounding areas with some noticeable exceptions. For example, seasonal activity was bimodal in Pennsylvania (Hulse et al., 2001) and southern New England (Klemens, 1993) populations of the North American Racer. However, in these studies, May either represented the primary peak activity month (Hulse et al., 2001) or it was shared with June (Klemens, 1993). Unimodality typified the seasonal activity pattern of the Milksnake in Pennsylvania (Hulse, 2001; Meshaka, 2010; Gray, 2011) and southwestern New England (Klemens, 1993), but was bimodal in northwestern Ohio (Meshaka et al., 2008). In all cases, including our study, May or June were peak months. Likewise, the Common Watersnake exhibited a single seasonal activity peak in our study and for Pennsylvania generally (Hulse et al., 2001) but were active in either May and somewhat less so in September in Connecticut (Klemens, 1993) or in May and August in Ohio (Meshaka et al., 2008).

In Pennsylvania and surrounding areas, seasonal activity pattern of the Common Gartersnake varied in its modality. Unimodal activity patterns of Pennsylvania populations peaked in May (Hulse et al., 2001), June (Meshaka, 2010), or July (Meshaka, 2009). Bimodal peaks in Pennsylvania occurred as early as April and June (Gray, 2011) and later in May and September (Meshaka, 2009). In Ohio, bimodal peaks in activity of the Common Gartersnake occurred in May-June and August (Meshaka et al., 2008) and in May-June and September in Connecticut (Klemens, 1993). Only the Ring-necked Snake maintained a single peak of activity (May, June, or both) in Pennsylvania (Meshaka and Wilkerson, 2008; Meshaka, 2010).

The strongly biased sex ratio favoring females among Common Gartersnakes at LEAD was typical of other studies in which cover boards were used in Pennsylvania (Meshaka, 2009, 2010) and Ohio (Meshaka et al., 2008). Although females could easily have been differentially attracted to these retreats as thermoregulatory sites for gravid females (Meshaka, 2010), the same pattern to sex ratios of the Common Gartersnake was found in a

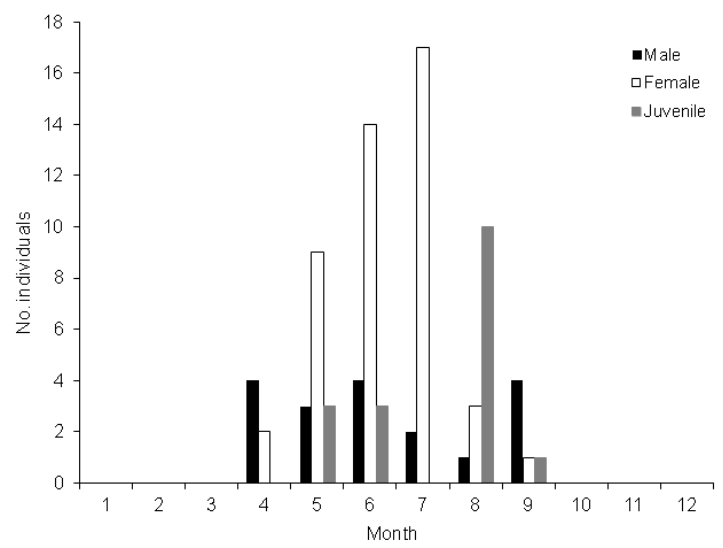

Figure 30. Monthly distribution of captures of male $(n=18)$, female $(n=46)$, and juvenile $(n=17)$ Common Gartersnakes (Thamnophis sirtalis) from Letterkenny Army Depot, Chambersburg, Franklin County, Pennsylvania, during 2008-2011. Five individuals of unknown status were captured in June. 
seasonal activity study based upon road surveys in the southern Everglades (Dalrymple et al., 1991). For other species sex ratios varied among sites. For example, the sex ratio was even in the Ring-necked Snake at LEAD, female-biased in southwestern Pennsylvania (Meshaka, 2010); however, males were more often encountered on roads in the southern Everglades (Dalrymple et al., 1991). Sex rations of both the Milksnake and Common Watersnake were even at LEAD, but comparisons with surrounding areas provided no clear pattern to sex ratios of these species. For example, sex ratios of the Milksnake could be even (Meshaka, 2010) or biased toward females (Meshaka et al., 2008). In Ohio, female Common Watersnakes were more frequently encountered than males (Meshaka et al., 2008).

The combination of small sample sizes despite four years of sampling and heavily skewed sex ratios in some of the species limited the extent to which sex-specific activity patterns could be detected in some of the species. Unimodal patterns of seasonal activity were most apparent in males of the North American Racer, Milksnake, and Common Watersnake, and females of the Ring-necked Snake, Common Watersnake, and Common Gartersnake, as well as in juveniles of the common Gartersnake. Bimodality may have been the pattern of seasonal activity in males of both the Ring-necked Snake, the Common Gartersnake, and possibly of females of the North American Racer. In Southwestern Pennsylvania, the modality of seasonal activity patterns of males of the Milksnake and both sexes of the Ring-necked Snake were similar to those at LEAD (Meshaka, 2010). In northeastern Ohio, similarity existed in the modality of seasonal activity of males of the Milksnake and of females and juveniles of the Common Gartersnake (Meshaka et al., 2008) with those of LEAD.

Body Size - Mean body sizes of adults at LEAD seemed to be more variable than those of other Pennsylvania sites, although the degree of sexual dimorphism in adult body size was more typical of Pennsylvania and northern populations generally. For example, mean body size of males and females of the Ring-necked Snake at LEAD were similar to those of southwestern Pennsylvania males (27.9 cm SVL) and females (27.7 cm SVL) (Meshaka, 2010), and at both sites, degree of sexual dimorphism in body size of adults was weak. For Pennsylvania generally (Meshaka and Wilkerson, 2008), males (mean $=26.5 \mathrm{~cm} \mathrm{SVL}$ ) were smaller than females (mean = $28.4 \mathrm{~cm} \mathrm{SVL}$ ). Likewise, in Connecticut, males (mean = $25.3 \mathrm{~cm} \mathrm{SVL}$ ) were smaller than females (mean $=27.2$ cm SVL) (Klemens, 1993). For all four studies, despite regional variation in body size dimorphism, the largest males were smaller than the largest females.

The North American Racer can attain a large body size in the North. Individuals at LEAD could reach $2 \mathrm{~m} \mathrm{TL}$, and Pennsylvania females were found to average 100.5 $\mathrm{cm}$ SVL (Hulse et al., 2001). The direction of body size dimorphism is not uniform in northern populations. For example, at LEAD males were only slightly larger than females, whereas males (mean $=95.7 \mathrm{~cm} \mathrm{SVL}$ ) were smaller than females across Pennsylvania (Hulse et al., 2001). However in Connecticut, the average male body size (mean $=99.7 \mathrm{~cm} \mathrm{SVL}$ ) was $12.7 \%$ larger than that of females (mean $=88.5 \mathrm{~cm} \mathrm{SVL}$ ) (Klemens, 1993).

Adult body sizes of the Milksnake and the extent and direction of their body size dimorphism varied widely across Pennsylvania and the other northern sites. For example, whereas average adult size of males and females from LEAD exceeded $70 \mathrm{~cm}$ SVL with males being larger $(5.4 \%)$, mean body size of males and females, and the percent difference in those values, respectively, differed among the following sites: southwestern Pennsylvania (68.0 and $66.0 \mathrm{~cm} \mathrm{SVL}, 3.0 \%$ ) (Meshaka, 2010), across Pennsylvania generally (72.6 and $67.7 \mathrm{~cm} \mathrm{SVL,}$ $7.2 \%$ ) (Hulse et al., 2001), Ohio (52.9 and $75.3 \mathrm{~cm} \mathrm{SVL,}$ $29.8 \%$ ) (Meshaka et al., 2009), and Connecticut (63.8 and $73.7 \mathrm{~cm} \mathrm{SVL}, 13.4 \%$ ) (Klemens, 1993).

In the Eastern Rat Snake the large mean adult body size of males and females was similar to that of males (121.7 $\mathrm{cm}$ SVL) and females (110.8 cm SVL) in Connecticut, where sample sizes were also small (Klemens, 1993), as in our study. Males (mean $=114.0 \mathrm{~cm} \mathrm{SVL}$ ) and females (mean $=112.6 \mathrm{~cm} \mathrm{SVL)}$ of the Eastern Rat Snake at PNR were smaller than those of LEAD but exhibited a similarly weak degree of body size dimorphism. A combined sample of both species from Pennsylvania indicated a generally smaller mean body size of males (107.8 cm SVL) and females (112.6 cm SVL) than in LEAD, and uncommonly, a reversal in body size dimorphism (Hulse et al., 2001).

In this study, the Common Gartersnake exhibited the greatest variability in body size, especially in the female. Despite this variation, body size dimorphism was consistently well-developed with smaller mean body sizes in males than in females, respectively: this study of LEAD (38.9 and $54.1 \mathrm{~cm}$ SVL), south-central Pennsylvania (41.3 and $49.8 \mathrm{~cm} \mathrm{SVL)} \mathrm{(Meshaka,} \mathrm{2009),} \mathrm{south-cen-}$ tral Pennsylvania (40.9 and $50.8 \mathrm{~cm}$ SVL) (Meshaka, 2009), southwestern Pennsylvania (39.6 and $47.3 \mathrm{~cm}$ SVL) (Meshaka, 2010), Pennsylvania (33.8 and $43.9 \mathrm{~cm}$ SVL, 23.0\%) (Hulse et al., 2001), Ohio (38.5 and 53.5 cm SVL, 28.0\%) (Meshaka et al., 2009), and Connecticut (39.6 and $50.0 \mathrm{~cm} \mathrm{SVL}, 20.1 \%$ ) (Klemens, 1993).

Clutch sizes - For all species but the Common Gartersnake, data on clutch characteristics were too few to make any generalizations. Monthly frequency of gravid females and young-of-the-year suggests August is the first and major month of parturition for the Common Gartersnake at LEAD. This pattern is similar to that found elsewhere in Pennsylvania (Meshaka, 2009, 2010) and in Ohio (Meshaka et al., 2009). Litter size averaged 15.3 at LEAD and was smaller than the mean value of 22.4 young reported for Pennsylvania (Hulse et al., 2001). Be-

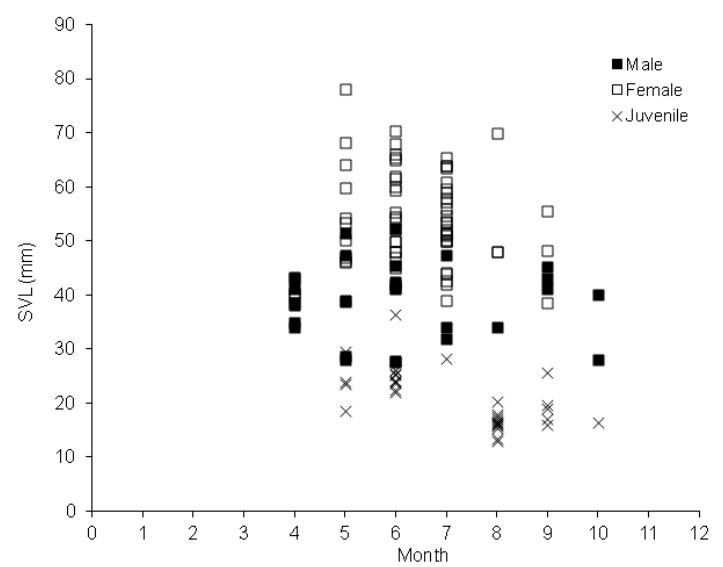

Figure 31. Monthly distribution of body sizes of male $(n=26)$, female $(n=64)$, and juvenile $(n=33)$ Common Gartersnakes (Thamnophis sirtalis) from Letterkenny Army Depot, Chambersburg, Franklin County, Pennsylvania, during 2008-2011. Data represent new individuals from standardized and opportunistic captures. 
cause female body sizes were not provided by Hulse et al. (2001), comparisons are difficult to make with our data. In an earlier study, we found that mean clutch size and female body size at LEAD were larger than those from southwestern Pennsylvania; however, litter size did not differ between sites when the effect of body size was removed (Meshaka and Delis, 2010). Despite similarity of the mean body size of the 27 gravid females that we palpated at LEAD ( $54.3 \mathrm{~cm} \mathrm{SVL})$ to that of five females (56.5 cm SVL) examined from Connecticut (Klemens, 1993), clutch size from Klemens' (1993) study averaged only 10.6 young. Here again, sample sizes limit the extent to which generalizations are possible, as do differences in methodologies, timing in the season of palpation, and potential for annual clutch size variation.

Resource Management Implications - Additional survey is necessary to determine if the low numbers of some species, such as the Red-bellied Snake (this study), the Eastern Ribbonsnake (Delis et al., 2010), the Eastern Hog-nosed Snake, and the Timber Rattlesnake as well as the absence of others known to inhabit Franklin County (Smooth Green Snake, Gray Ratsnake, Common Wormsnake, and Queen Snake, Regina septemvittata (Say, 1825), accurately reflect the snake assemblage of LEAD. Past land use practices by the military and land holders preceding acquisition of LEAD by the DOD could explain contemporary absences or rarity of species through persecution, habitat alteration or both.

Continued monitoring is also necessary to provide data sufficient to analyze growth, survivorship, diet, and reproductive parameters associated with these habitats. However, at present our findings provide data that corroborate patterns of seasonal activity, habitat use, and the influence of the North American Racer on demographic traits from Pennsylvania and surrounding areas. In our opinion, a key factor to the health of the snake community is the presence of a mixed landscape composed of open habitats, close canopy, and wetlands resulting in a mosaic landscapes which appear to promote higher snake diversity.

Our findings also identify responses, such as sex ratios that were not found to follow any clear pattern in the North. Our study should serve to underscore the striking differences in snake assemblage structure not only among regions but among habitats that are near one an-

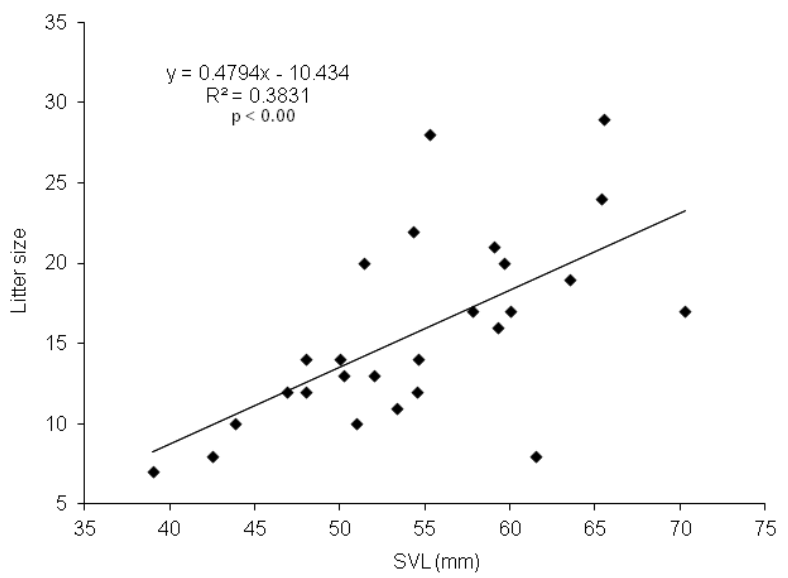

Figure 32. Relationship between litter size and female body size in the Common Gartersnake (Thamnophis sirtalis) from Letterkenny Army Depot, Chambersburg, Franklin County, Pennsylvania, during 2008-2011. other, thereby providing researchers with more data to test ecological predictions and resource managers with information to make sound conservation decisions in the future in such large and heterogeneous systems as LEAD.

\section{CONCLUSIONS}

The species detected in our study were expected based on geographic range and general habits. The species not detected in our study were those that were rare or thought to have been rare on LEAD, or for others, absent. Patterns of snake assemblage structure and composition were associated both by habitat and by the presence of the North American Racer.

As is southwestern Pennsylvania (Meshaka, 2010), the snake assemblage of LEAD was unimodal in its seasonal activity pattern, the peak of which, however, was earlier owing to a warmer climate.

Individual species and, in general, males were unimodal in their seasonal activity patterns at LEAD. Modality of seasonal activity patterns could vary among species in Pennsylvania and surrounding areas, but the months of greatest activity exhibited greater conformity among sites. Comparatively, the greatest consistency in modality of seasonal activity in Pennsylvania and surrounding areas was found in the Milksnake (males), the Common Gartersnake (females and juveniles), and the Ringnecked Snake (both sexes). Skewed sex ratios favoring females consistently occurred in the Common Gartersnake in Pennsylvania and surrounding areas.

Body sizes of adult females of the Common Gartersnake and males of the Milksnake were correlated with the presence of the North American Racer. The largest snake in LEAD was the North American Racer, and the smallest species was the Red-bellied Snake. Litter sizes of the Common Gartersnake averaged 15 young, were body size-dependent, and were variable among sites. Additional study could determine the status of rare or absent species in our study area, whereas data thus far collected provided information useful when formulating resource management plans, such as the protection of wetlands and the expansion of open habitats such as prairies.

\section{ACKNOWLEDGEMENTS}

We extend our gratitude to the staff of Letterkenny Army Depot, and the base commander, Colonel Provancha. Especially, we would like to thank the Resource Manager, Craig Kindlin, for his support in this and other research projects we have undertaken on the base.

\section{LITERATURE CITED}

Conant, R. \& Collins J. T. (1998). Reptiles and Amphibians of Eastern/Central North America. 3rd ed. Houghton Mifflin Co. New York, New York, USA.

Dalrymple, G.H., T.M. Steiner, R.J. Nodell, and F.S. Bernardino, Jr. 1991. Seasonal activity of the snakes of Long Pine Key, Everglades National Park. Copeia1991:294-302.

Delis, P.R., C. Kindlin, and R.L. Stewart. 2010. The Herpetofauna of Letterkenny Army Depot, south-central Pennsylvania: A starting point to the long-term monitoring and management of amphibians and reptiles. Journal of Kansas Herpetology 34:11-16.

Fitch, H.S. 1999. A Kansas Snake Community: Composition and changes Over 50 Years. Krieger Publishing Company, Malabar, Florida, USA.

Gray, B.S. 2011. Seasonal activity and natural history observations of five snake species from the central 
Iowland province of Erie County, Pennsylvania. Journal of Kansas Herpetology 38:13-20.

Hulse, A. C., C. J. McCoy, \& E.J. Censky. (2001). Amphibians and Reptiles of Pennsylvania and the Northeast. Cornell University Press. Ithaca, New York, USA.

Kjoss, V.A. and J.A. Litvaitis. 2001. Community structure of snakes in a human-dominated landscape. Biological Conservation 98:285-292.

Klemens, M.W. 1993. Amphibians and Reptiles of Connecticut and Adjacent Regions. 1993. State Geological and Natural history Survey of Connecticut. Bulletin No. 12. 318 pp.

Meshaka, W.E., Jr. 2009. Seasonal movements and parturition seasons of the common garter snake (Thamnophis sirtalis) from two sites in south-central Pennsylvania. Journal of the Pennsylvania Academy of Science 82:51-54.

Meshaka, W.E., Jr. 2010. Seasonal activity and breeding seasons of snakes from Powdermill Nature Reserve in western Pennsylvania: the importance of sitespecific data in land management programs. Herpetological Conservation and Biology 5:155-165.

Meshaka, W.E., Jr. and J.T. Collins. 2009. A Pocket Guide to Pennsylvania Snakes. Mennonite Press. Newton, Kansas, USA.
Meshaka, W.E., Jr. and P.R. Delis. 2010. Clutch sizes in two populations of the Eastern Garter Snake (Thamnophis sirtalis) in Pennsylvania. IRCF Reptiles and Amphibians 17:206-208.

Meshaka, W.E., Jr., S.D. Marshall, and T.J. Guiher. 2008. Seasonal activity and reproductive characteristics of an oldfield-grassland snake assemblage: Iimplications for land management. Herpetological Bulletin 105:35-40.

Meshaka, W.E., Jr., S.D. Marshall, T.J. Guiher, and L. Zemba. 2009. Grassland snake assemblages in central and western Pennsylvania and northeastern Ohio. Herpetological Bulletin 110:8-19.

Meshaka, W.E., Jr. and M.L.D. Wilkerson. 2008. Seasonal activity, reproduction, and growth of the ringneck snake (Diadophis punctatus) in Pennsylvania. Journal of Kansas Herpetology 28:17-20.

Mitchell, J.C. 1994. The Reptiles of Virginia. Smithsonian Institution Press. Washington, DC., USA.

Palmer, W.M. and A.L. Braswell. 1995. Reptiles of North Carolina. University of North Carolina Press. Chapel Hill, North Carolina, USA.

Uhler, F.M., C. Cottam, and T.E. Clarke. 1939. Food of snakes of the George Washington Forest, Virginia. Transactions of the Fourth North American Wildlife Conference 605-622. 